\title{
血液透析中のリンパ球ロゼット形成細胞の動態
}

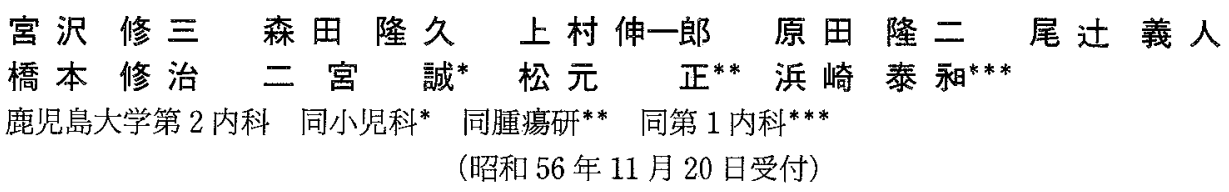

Key words : lymphocyte subpopulation, hemodialysis, suppressor $\mathrm{T}$ cell, $\mathrm{T} \gamma$ cell, leukopenia

〈要旨〉

血液透析が免疫応答系, 特に末梢血リンパ球 subpopulation に及ぼす影響について検索した。対象は週 3 回の維持透 析を受けている安定期の患者で, cuprophan膜を用いて透析を行っている者 10 例と polycarbonate membrane (PCM) を用いている者 2 例とした。 方法はこれらの症例で, 透析前, 透析開始後 15 分，60 分，120 分に採血を行い, 白血球算定, アナリーゼ，補体価の測定，及び矢田らの mixed rosette 法を用いてリンパ球 subpopulation の測定を

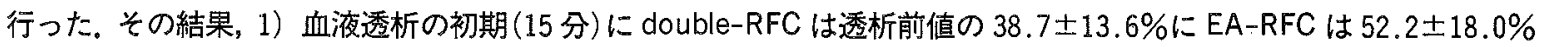
に著明 $(P<0.001)$ に減少し，60 分には回復した。今回減少を示した double-RFC は T $y$ cell であり suppressor T cell 及び killer T cell の一部である。また EA-RFC は B cell, K cell を含む subsets である。2）透析中に T細胞の比率に は変動は認められなかった。3）透析中にリンパ球数は $20 \%$ 前後の減少を認めた。䒓の主体は double-RFC およびEA -RFC の減少と思われる。4）これら subsets の減少にはIgGの Fcレセプターを介したメカニズムの関与の可能性が 考えられる。5）透析初期の好中球や単球の減少には補体の活性化を介さないメカニズムも存在すると思われる。

\section{The changes of rosette forming cell of peripheral blood lymphocyte during hemodialysis}

Shuzo Miyazawa, Takahisa Morita, Shinichiro Uemura, Ryuji Harada, Yoshito Otsuji Shuzi Hashimoto, Makoto Ninomiya*, Tadashi Matsumoto**, Yasunaga Hamasaki***

The 2nd Department Internal Medicine, Faculty of Medicine, Kagoshima University, Pediatrics *, Institute of Cancer Research**, The 1st Department of Internal Medicine ${ }^{* * *}$

The effect of hemodialysis on the immune response, mainly on the peripheral blood lymphocyte subpopulation, was studied. Ten(10) patients on maintenance hemodialysis using cuprophan membrane and 2 patients using polycarbonate membrane had been subjected to our study and lymphocyte subpopulations had been made according to Yata's mixed rosette method. The blood was withdrawn from the patients at intervals of 15, 60 and 120 minutes in addition to predialysis. Results are as follows : 1) Percentages of subsets of double-RFC (Ty cells : suppressor T cells and a part of killer cells) and EA-RFC ( $B$ cells and $K$ cells) decreased markedly in the peripheral blood within 15 minutes after starting of hemodialysis and thereafter returned to former figures after 60 minutes $(P<0.001)$. 2) There was no significant alteration of $T$ cell count percentage in the periferal blood. 3) There was about $20 \%$ decrease of lymphocytes in number during dialysis, which was considered to be attributed mainly to decreased numbers of double-RFC and EA-RFC. 4) A mechanism which might have affected those subsets through Fc receptors of IgG was appeared to be one of possible causes of the subsets decrease. 5) Decrease of the neutrophils was not solely attributed to complement activation mechanism. The other mechanism was suggested to be responsible for the phenomenon.

はじめに

近年，人工透析療法の著しい進歩に伴い，慢性腎不全 患者の長期延命が可能となった。 5 年生存率はおおおう
$80 \%$ に達する施設もでてきて放り”，いまや最長生存期 間仗 10 年を越えている。しかし，長期延命が可能になれ ばなる程, 腎不全という病態が透析によって充分に改善 
されないための障害と, 透析することによって生ずる新 しい病態とが問題になってきている。

血液透析が免疫応答系に及汸す影響については多くの 報告があり，なかでも白血球，特に，好中球や単球が， 透析初期に著明に減少するとの報告がある ${ }^{2 \sim 4)}$. しかし， リンパ球についての詳細な研究報告はほとんどない.

さて，リンパ球にはT細胞，B細胞があり，B細胞は 抗体産生能を有し, T細胞は移植拒絶反応, 遅延型アレ ルギー反応，抗体産生細胞に対する helper や suppressor などがあり，それらを担当する機能別 subsets の存在が知られている。 IgGの Fc 部分に対するレ セプターをもつT細胞 ( $\mathrm{T} \gamma$ cell) は suppressor T cell 及 び killer T cell の一部に一致すると報告されている ${ }^{5 \sim 7)}$. 我々はすでに慢性腎不全の患者の末梢血リンパ球 subpopulation について検討し, T細胞, B 細胞比率には変 化はないものの $\mathrm{T} \gamma$ cell が患者群で有意に増加している ことを発見し，腎不全患者に打ける免度不全とのかかわ りあいについて報告した ${ }^{8,9)}$. 今回はこれらリンパ球 subpopulation が血液透析中にどのような影響を受けるか について検索した ${ }^{10)}$.

\section{実験方法}

(1) 対象：教室の関連施設で 1 週 3 回 5 時間の維持透 析を行っている安定期の患者で, cuprophan 膜 dialyzer 使用者 10 例と polycarbonate membrane (PCM) dialyzer 使用者 2 例を対象とした。

(2) Blood sampling：採血は血液透析開始前, 開始後 15 分(HD 15 分), 60 分, 120 分にそれぞれへパリン加血 として採取した。透析開始前は $\mathrm{A}-\mathrm{V}$ シャシト部の静脈か ら, その他は血液回路の静脈側から各々 $13 \mathrm{~m} l$ 採取した。 採取したsampleは小わけにし， $1 \mathrm{~m} l$ は白血球の算定及 びアナリーゼに用い， $2 \mathrm{~m} l$ は補体価の測定に，また10 $\mathrm{m} l$ はリンパ球 subpopulation の測定に供した。

（3）リンパ球の分離：採取した $10 \mathrm{~m} l$ のヘパリン加 血に $1 \mathrm{~m} l$ の carbonyl ironを加光, $37^{\circ} \mathrm{C} て ゙ 60$ 分間 incubateし，充分に phagocytosisさせた後, Ficoll Hypaque 比重遠心法 (3000 rppm：25 分)により monocyte を除去したリンパ球を分離した ${ }^{11}$. この方法による 末梢血からのリンパ球回収率は $86.0 \%$ であり,リンパ球 純度 $99.9 \%$ (monocyteのリンパ球への混入率は $0.1 \%$ 以下）であった。

(4) リンパ球 subpopulationの測定: 矢田ら ${ }^{12)} の$ mixed rosette 法を用いて行った。前述の方法で得たり ンパ球 $5 \times 10^{5}$ 個を $0.1 \mathrm{~m} l$ の phosphate buffered saline (PBS) の下に抗ニワトリ赤血球・ウサギ IgG で coating したニワトリ赤血球 $\left(\mathrm{EA}: 1 \times 8^{8}\right.$ 個 $\left./ \mathrm{m} l \mathrm{PBS}\right)$ を $0.1 \mathrm{~m} l$ 加え, $4^{\circ} \mathrm{C}$ で 6 時間 incubationした後, 静かに上清を捨
て, 非働化した胎児ウシ血清 fetal calf serum (FCS) 0 . $1 \mathrm{~m} l$ を加え, さらに FCS $1 \%$ 濃度に浮遊させたヒツ 浾血球 $\left(\mathrm{E}: 5 \times 10^{8}\right.$ 個 $\left./ \mathrm{m} l \mathrm{FCS}\right) 0.1 \mathrm{~m} l$ 加え混和後 200 $\mathrm{G}, 5$ 分間遠心し, $0^{\circ} \mathrm{C}$ over night に反応させスライドグ ラスにのせ, ブリリアントで染色し, 光顕的にロゼット 形成性を観察した。この方法によるロゼット形成細胞は ヒツジ赤血球とのロゼット形成細胞 $(\mathrm{E}-\mathrm{RFC})$, ニワトリ 赤血球との口ゼット形成細胞(EA-RFC), またヒツジ赤 血球 $(\mathrm{E})$ 及びニワトリ赤血球（EA）と同時にロゼッ卜 形成するダブルロゼット形成細胞 (double-RFC, E+ $\mathrm{EA}-\mathrm{RFC}$ )の 3 種類であった。また，いずれともロゼッ 卜形成しない null cell も観察された。 E-RFCはヒツジ 赤血球 3 個以上と結合しているものを, EA-RFC はニワ トリ赤血球 2 個以上と結合しているものを陽性とし, こ れらを 250 個以上数え，それぞれの百分率を求めた。以 上の方法で検出された $\mathrm{E}-\mathrm{RFC}$ は $\mathrm{T}$ 細胞であり, IgGの Fc 部分に対するレセプターを保有しないもの, double$\mathrm{RFC}$ はT細胞であり, かつ IgGの Fc 部分に対するレセ プターを保有するもの (T $\gamma$ cell) と評価した。またT細 胞は E-RFC と double-RFC (T $y$ cell) の総和として求 めた. EF-RFC は IgGのFc 部分に対するレセプターを 保有する non T cell fractionである。

（5）補体価の測定：Mayerの方法を用いて測定した。 成績

血液透析中の白血球の動態：cuprophan膜使用時の白 血球の変化について図 1 に示した。好中球は透析開始 直後から著明に減少し, H D 15 分には HD 前値の 26 .

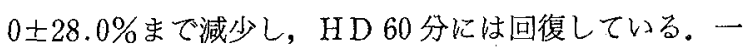
方リンパ球は透析初期より減少傾向を示すが，最大值で も $80.4 \pm 19.6 \%$ までの減少であった.PCM 使用時の白 血球の変化は図 2 に示した。好中球は cuprophan 膜使用 時と同様，透析初期に著明に減少した。リンパ球は $70 \%$ までの減少を示した。

リンパ球 subpopulationの動態：cuprophan 膜使用 時の末梢血リンパ球 subpopulaton の動態を図 3 に示し た。すなわち, 末梢血中での各々のリンパ球 subsets の比 率が透析中どのように変動したかを透析前值に対する比 率として求め示したものである。double-RFC は HD 15 分に $38.7 \pm 13.6 \%$ にまた EA-RFCも同様にH D 15 分 には $52.2 \pm 18.0 \%$ に有意 $(\mathrm{p}<0.001)$ に減少し, 60 分に は回復している。これとは逆に E-RFCはHD 15 分に $118.4 \pm 21.3 \%$ と増加し，また null cellも $143.7 \pm 72.9$ \%と著明に増加し, 60 分以降次第に回復してきている. しかし,一方, E-RFC と double-RFC の和として算出さ れる T細胞の HD 前值に対する比率は HD 15 分 102 . $2 \pm 7.5 \%, H D 60$ 分 $100.7 \pm 7.8 \%$, HD 120 分 $99.0 \pm 4$. 


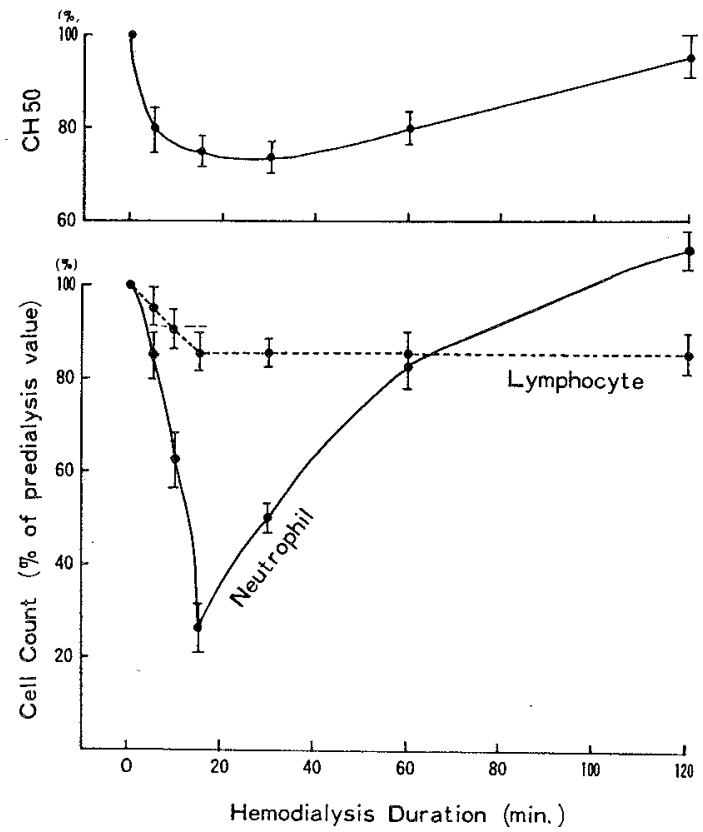

図 I The chages of total complement activity and leukocyte counts in patients during hemodialysis using cuprophan membrane dialyzer.

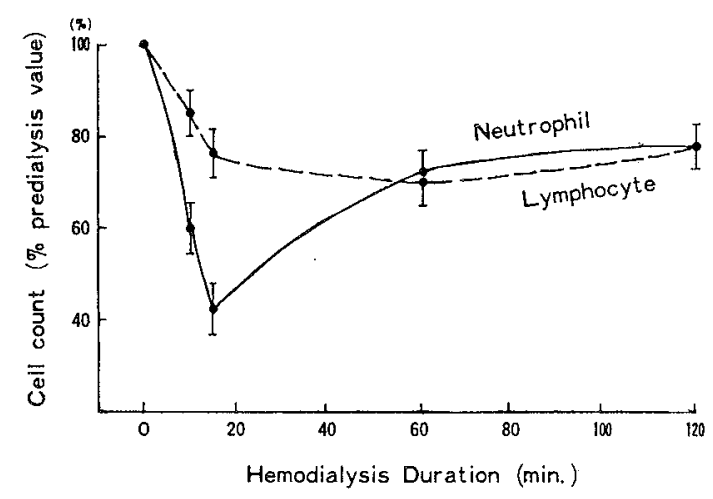

図 2 The changes of leukocyte counts in patients during hemodialysis using polycarbonate membrane (PCM) dialyzer.

$3 \%$ と推移し，HD 前値とほぼ同じ比率を示した。

次にこれら各 subsets の末梢血での実数が，HD 中に どの様な変動を示すかを図 4 に示した. Double-RFC は 実数でも同様に HD 15 分に $32.9 \pm 15.5 \%$ と有意 $(\mathrm{p}<$ 0.001)に減少した.EA-RFCもHD 15 分には $42.8 \pm 19$. $6 \%$ と著明に減少 $(\mathrm{p}<0.001)$ ，両者共に HD 60 分に は回復している. E-RFC はリンパ球実数が減少傾向に あったにもかかわらず，HD 15 分には $107.5 \pm 47.5 \%$ と 増加したが 60 分では $85.5 \pm 24.8 \%, 120$ 分は $86.8 \pm 16$. $9 \%$ と減少の傾向を示した. null cell は HD 15 分に 123.

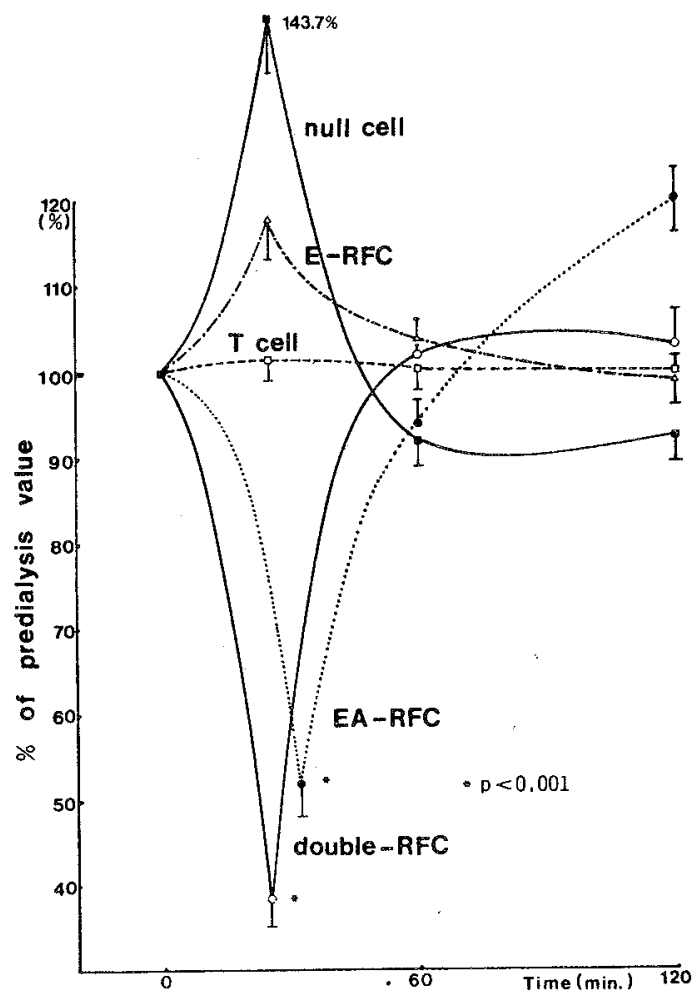

図 3 The changes of the proportions of lymphocyte subpopulations in uremic patients during hemodialysis using cuprophan membrane dialyzer.

$2 \pm 60.2 \%$ と増加し, 以後減少している. T cell は HD 15 分には $84.5 \pm 30.3 \%, H D 60$ 分では $83.0 \pm 20.0 \%$ ， HD 120 分では $90.4 \pm 13.2 \%$ と推移した。

図 5,6 は今回 HD 初期に著明に減少を示した double -RFC，EA-RFC の subsets が個々の症例で末梢血中の 比率がどのように推移したかを示したものである。 Double-RFC は HD 15 分には全例が HD 前值の $60 \%$ 以 下に著明に減少した。1 例は HD 15 分に $8.9 \%$ まで著明 に減少し, HD 60 分では逆に $377.4 \%$ と強い rebound を 示し, HD 120 分に正常化した。他の1例では, HD 15 分 に 56.5\%,HD 60 分に $26.1 \%$ と更に減少したが HD 120 分には $70 \%$ と回復してきた。 EA-RFC は 9 例で HD 15 分に著明に減少している。しかし 1 例は HD 15 分に 84 \%まで軽度に減少し, HD 60 分には $201.7 \%$ と強い reboundが起こり,120分值はsamplingしたリンパ球数が少 なかったため測定できなかったが，HD終了時(300分)に は HD 前值のレベルまで回復していた。いずれにしても double-RFC, EA-RFC は HD 中に程度の差はあるが， 全例が HD 初期に減少し, HD 120 分には回復している。 


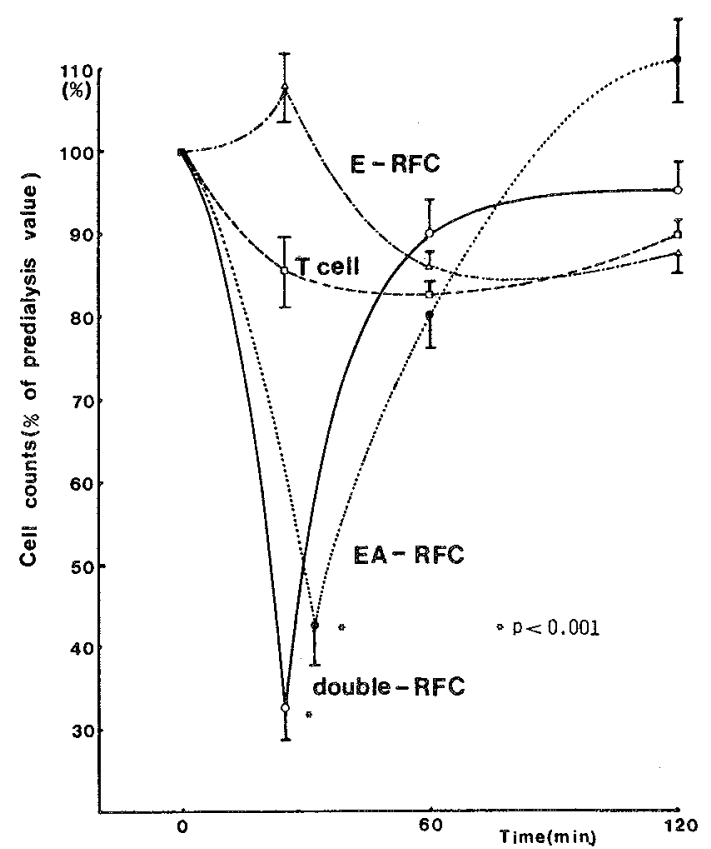

図 4 The changes of the absolute number of each lymphocyte subpopulation in ure. mic patients during hemodialysis using cuprophan membrane dialyzer.

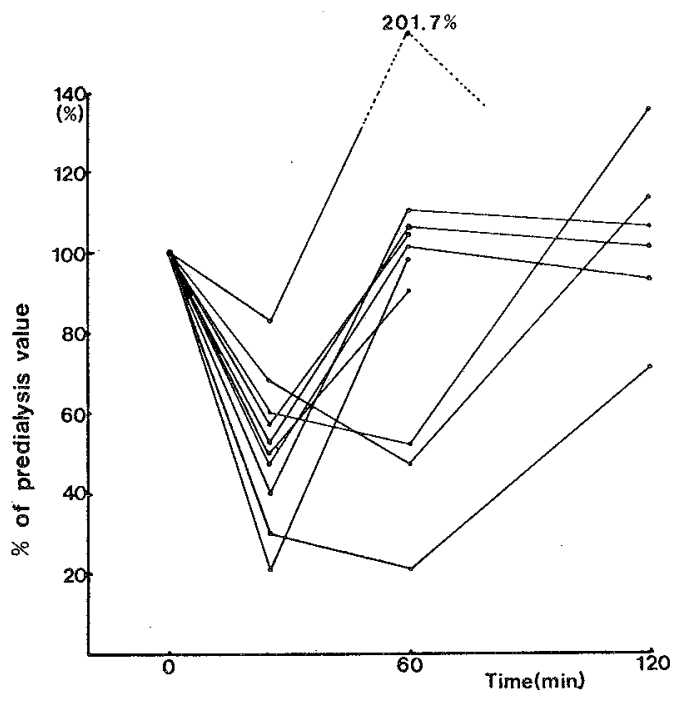

図 5 Individual changes of EARFC using cuprophan membrane dialyzer

PCM 使用時のリンパ球 subpopulationを図 7 に示し た. 2 例とも cuprophan 膜使用時と同様の傾向を示した が，減少率はやや軽度であった。HD 中の補体価は図 1 ， 8 に示したが, cuprophan 膜使用時には HD 初期より， CH 50 の低下が起こっている。しかし，PCM 使用時には

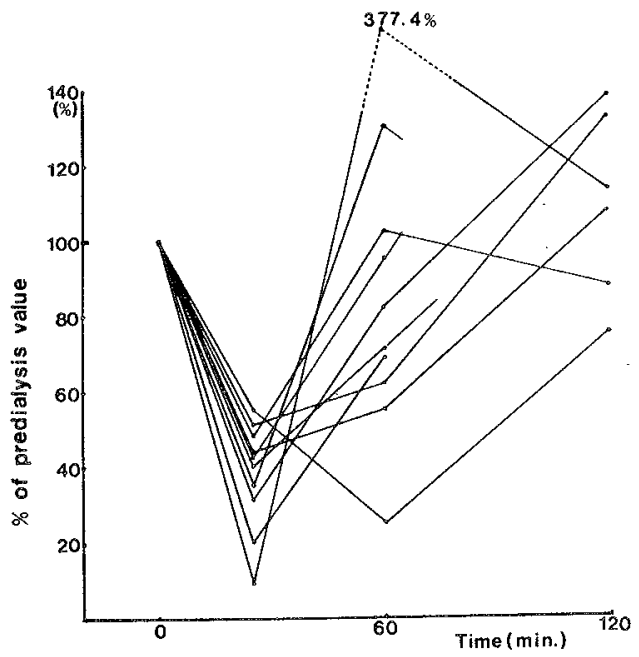

図 6 Individual changes of double-RFC using cuprophan membrane dialyzer.

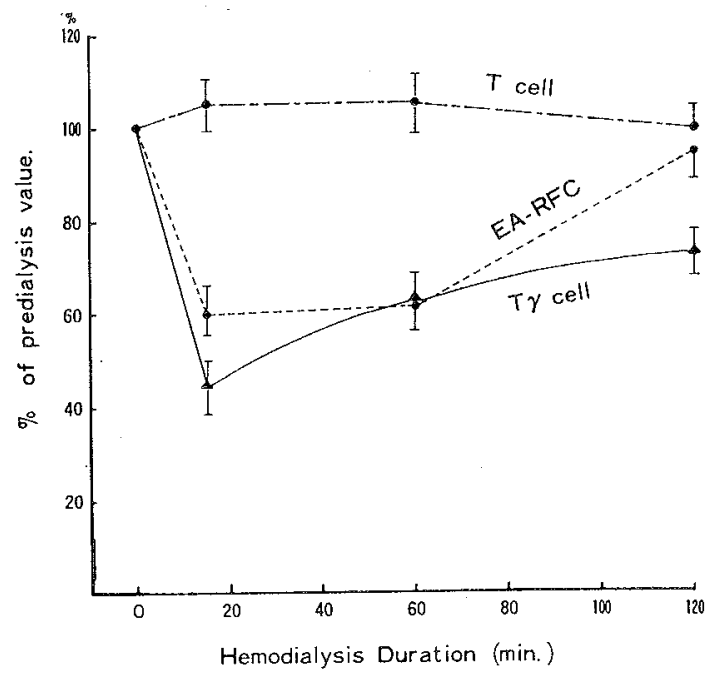

図 7 The changes of the proportions of lymphocyte subpopulations in uremic patients during hemodialysis using polycarbonate membrane (PCM) dialyzer.

\section{CH 50 の有意の低下は認められなかった。}

\section{考察}

今回，我々の検索で，血液透析の初期にリンパ球のあ る subsets (double-RFC 及び EA-RFC) が著明に減少す ることを観察した。

血液透析が白血球系に及ぼす影響については古くから 多くの報告がある.Kaplow ら ${ }^{2)}$ により血液透析の early phase に好中球が著明に滅少することが初めて報告され た。彼らは好中球の動員の場は dialyzer ではなく，患者 


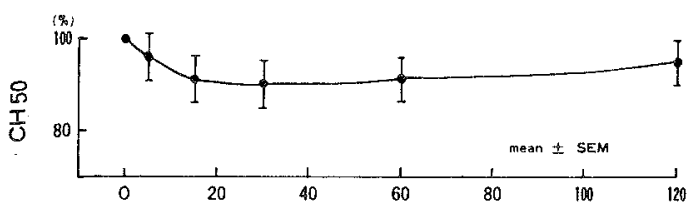

図 8 The changes of total complement activity (CH50) in patients during hemodialysis using polycarbonate membrane (PCM) dialyzer.

体内であるとするものの，その原因は患者血液が dialyzerを通過することにより惹起されるとしている。 Craddock $ら^{3)}$ は血液透析中に同様の白血球減少を観察 し，その主体は好中球と単球であるとしている。さらに 彼らは，ウサギを用いた実験で, dialyzerの cellophane membrane により，factor $\mathrm{B}$ ，補体 $\mathrm{C}_{3}$ が活性化され， いわゆるalternate pathwayの活性化が起こり,その結果, 好中球や単球が肺毛細血管にleukostasisを起こし，末梢 血での好中球や単球の減少が起こることをつをとめ, ヒト でも同様のメカニズムで起こるだろうとしている。Nusbacher ${ }^{13)}$ はnylaon fibreでも同様の補体活性化と顆粒 球の減少が起こるとしている。しかしAljamaら ${ }^{14)}$ はcuprophan膜の他に PAN (polyacrylonitrile) 膜, polycarbonate membrane (PCM) dialyzerを用いて実験を 行い，cuprophan膜では補体の活性化と同時に好中球の 隇少が起こるが,PAN膜では補体の活性化は起こるものの， 好中球の減少はみられず，またPCMでは補体の活性化 は起こらず,好中球の減少のみを認めるとして，好中球の 隇少には多くの原因があり，補体の活性化が主因でない としている。我々の今回の実験でもcuprophan膜では補 体の活性化と同時に好中球の減少を認めたが，PCMで は補体の活性化は起こらず,好中球の減少のみを認め,好 中球減少には補体の活性化とは別の因子の存在の可能性 が示唆された。さて血液透析中のリンパ球の動態につい ての報告はほとんどない. Kaplow, Craddock らはそれ ぞれ独自に透析中にリンパ球実数が 10〜20\%減少する とし, 中林ら ${ }^{15)}$ は透析初期にリンパ球は 30〜 $50 \%$ の減少 を認めたが，T細胞，B細胞の比率には変化は認められ なかったとしている。今回の我々の観察でも，透析中T 細胞の未梢血中での比率は HD 前 $79.8 \pm 7.4 \% ， H D 15$ 分 $81.3 \pm 7.4 \%, H D 60$ 分 $80.1 \pm 7.5 \%$, HD 120 分 79 . $5 \pm 7.0 \%$ と推移し，T細胞比率に変動は認められなかっ た。しかし，double-RFC ( T $\gamma$ 細胞) 及び EA-RFC (B 細胞 $\mathrm{K}$ 細胞を含专 fraction) は透析初期に著明に減少し， これとは逆に E-RFC ( T $\gamma$ 細胞を除くT細胞), null cell は増加を示した。

今回減少を示したdouble-RFC (Ty cell) はヒトでは
Moretta ら゙により機能的解析がなされ, poke weed mitogen (PWM) により誘導される B 細胞の polyclonal differentiation suppress すること，また K cell activity を有することなどにより，マウスにおける5,6)と 同様に suppressor $\mathrm{T}$ cell 及び killer $\mathrm{T}$ cell の一部との 相関が確認されている。また EA-RFCは IgGの Fc 部分 に対するレセプターを保有する non $\mathrm{T}$ cell fractionで あること，さらに Ficoll-Hypaque 比重遠心法でリンパ 球層に contaminateすると考えられる monocyteを除 去してあることにより，B 細胞及び K cell を含む subset と考えられる。従って今回の実験結果は suppressor T cell, killer T cell, B cell, K cell の減少と受けとられ る。しかし，今回の测定法ではリンパ球のヒツジ赤血球 に対するレセプターと IgGの Fc 部分に対するレセプタ ーの検出であることを考光れば，血液が dialyzer を通過 する時何らかのメカニズムでFcレセプターが maskさ れ，その結果 double-RFC の減少は E-RFC の増加に， EA-RFC の減少は null cell 分画の増加に変換された可 能性も否定できない。しかしながら，リンパ球実数が透 析中 $20 \%$ 前後の減少を示していること, また，各サブセ ットの実数の変動（図 4) でも T 細胞数が減少している 事実は,レセプターがmaskされたためだとするだけでは 説明できない.Fcレセプターが maskされた細胞が体内 であるいは dialyzer 内で entrapされたか，あるいは mask とは無関係に Fcレセプタ一の関与した別のメカ ニズムの体内のどこかでまたは dialyzer 内で entrapさ れた可能性が強い。また好中球の減少が補体の活性化に よるとするCraddockらと同様の機序で起こるとする可能 性はcuprophan膜では考光られても，PCMでは補体の 活性化は起こっていないのにもかかわらずdouble-RFC, EA-RFC は減少していることからも否定的である。ま た，かりに補体が活性化され，補体レセプターが関与し たと仮定しても EA-RFC は B 細胞，K細胞であり，Creceptor が存在するが, double-RFC \& (suppressor T cell 及び一部 killer T cell であり) この subsetsに含ま れる killer T cell の一部に C-receptor が存在するだけ で suppressor T cell には C-receptor は存在せず，この 点からも，補体の関与は否定的である。いずれにしても， リンパ球 subsetsの減少には IgG の Fc receptorを介し たメカニズムの関与の可能性がより考えられる。今回減 少したリンパ球は suppressor T cell や移植拒絶反応を つかさどる killer T cell，ADCC を担当する K cell，抗 体を産生するB cell を含む subsetsである。この様に免疫 応答系で重要な役割を担当する細胞が，血液透析を受け る度に患者未梢血中でダイナミックに変化すること怙， 何を意味するかは不明であるが，生体にとって好ましい 
こととは考えられない. 従来 BUN, creatinine の clearance や ultrafiltration などの面から dialyzerへの評価 がなされていたが，最近各種 parameter 用いて dialyzer の生体適合性への研究がなされつつある。このよ うな観点から，リンパ球 subpopulation の測定は有力な parameterの1つとなりうると考える。

\section{結論}

(1) 血液透析初期に末梢血中のリンパ球 subsets double-RFC ( $\mathrm{T} \gamma$ cell, suppressor $\mathrm{T}$, killer $\mathrm{T}$ ), EARFC (B cell，K cell) の比率が著明に減少し，HD 60 分 には回復する $(\mathrm{p}<0.001)$ 。

（2）透析中，末梢血中の $\mathrm{T}$ cell percentage は変動し ない。

（3）透析中，リンパ球実数は $20 \%$ 前後の減少を認め る。その主体は double-RFC 及びEA-RFC の減少と思 われる。

(4) これら subsets の減少には IgGの Fcレセプター を介したメカニズムの関与の可能性が考えられる.

（5）透析初期の好中球の減少には補体の活性化だけが 原因とは考光られず，他のメカニズムの存在の可能性も 考光る必要がある。

本論文の要旨は第 8 回国際腎臟学会 (ATHENS 1981 年), 第 23 回日本腎臓学会総会 (東京, 1980 年), 第 23, 26 回人工透析研究会 .(大阪 1979 年，横浜 1981 年) で発 表した。なお今回使用した polycarbonate membrane (PCM) は米国より取り寄せ，plate型に成型したものを 使用した。

\section{文献}

1）三村信英, 原茂子, 二瓶宏, 南方保：系統疾患の透 析，腎と透析 8(1)：79-89，1980.

2) Kaplow, L.S., Goffinet, J.A. : Profound neutrophilpenia during the early phase of hemodialysis. JAMA., 203 : 133-135, 1968.

3) Craddock, P. R., Fehr, J., Dalmasse, A.P., Brigham, K.L., Jacob, H.S. : Hemodialysis leukopenia : Pulmonary vascular leukostasis resulting from complement activation by dialyzer cellophane membranes. J. Clin. Invest., $59: 879$ 883, 1977.

4) Toren, M., Goffinet, J.A., Kaplow, L.S. : Pulmonary bed segue stration of neutrophils during hemodialysis. Blood, 36 (3) : 337-340, 1970.

5) Yoshida, T.O., Anderson, B. : Evidence for a receptor recognizing antigen complexed immunoglobulin on the surface of activated mouse thymus lymphocyte. Scand. J. Immunol., $1: 401-$ 406, 1972.

6) Herzenberg, L.A., Okumura, K., Cantor. H., Sato, V.L., Shen, F.W., Boyse, E.A. : T cell regulation of antibody responses: Demonstration of allo type-specific helper $\mathrm{T}$ cells and their specific removal by suppressor T cell. J.Exp. Med., 144 : 330-344, 1976.

7) Moretta, L., Webb, S.R., Grossi, C.E., Lydyard, P. M. : Functional analysis of two human $T$-cell subpopulation: Help and Suppresion of B-cell responses by $\mathrm{T}$-cells bearing receptors for IgM or IgG. J.Exp. Med., 146 : 184-200, 1977.

8）松元正，宮沢修三，上村伸一郎，尾汁義人，橋本修 治：人工透析患者の Fc レセプター陽性 T リンパ球 の動態について, Acta. Heam. Jap. 40 : 726, 1977.

9）松元正，宮沢修三，上村伸一郎，尾汁義人，橋本修 治, 松元実, 柚木一雄：慢性腎不全患者に抢ける IgG -Fc receptor 陽性 Tリンパ球の動態。医学のあゆみ $103: 752-753,1977$.

10）宮沢修三：透析患者の細胞性免疫能，未梢血リンパ 球 subpopulation の側面から, 人工透析研究会会誌 $12: 629-630,1979$

11）安保徹, 熊谷勝男: Carbonyl iron と Ficoll Isopaque 法によるリンパ球の純分離, 医学のあゆみ $97: 336-337,1976$.

12）新保敏和，矢田純一，中川俊郎，漆畑修，松元正： ヒト IgG-Fc receptor 陽性 Tリンパ球の検出法と 各種疾患に抢ける変動, 臨床免疫 $9(2) ： 141-145$, 1977.

13) Nusbacher, J., Rosenfeld, S.I., MacPhersan, J.L., Thiem, P.A., Leddy. J.P. : Nylon fiber leukapharesis: Associated complement changes and granulocytepenia. Blood $51: 359-365,1978$.

14) Aljama, P., Bird, P.A., Ward, M.K., Fest, T.G., Walker, W., Tanboga, H., Sussman, M., Kerr, D. N.S. : Hemodialysis induced leukopenia and activation of comklement: Effects of different membranes. EDTA $15:$ 144-153, 1978.

15）中林公正, 長沢俊彦, 高橋裕子, 木村常雄, 小林由 美, 大高宏：Cuprophan 膜コイルによる血液透析時 の白血球数, その百分率, リンパ球 subpopulation の 変動とその成因についての考察，腎と透析 7： 177-182, 1979 .

16）芝本隆, 松井則明, 小沢潔, 中村義弘, 秋葉隆, 吉 出直樹, 中川成之輔, 根本毅志, 北岡建樹：Dialyzer 
の生体適合性評価の示標としての beta-thromboglobulin に関する検討, 人工臟器 10 (1) : 98-101, 1981.

17）志戸本宗徳，尾辻省悟：慢性腎不全における各種グ
アニジン誘導体の変動, 日腎誌 $21: 33-49,1979$ 。

18) Akizawa, T., Nishiyama, H., Koshikawa, S. : Plasma $\beta$-thromboglobulin levels in chronic renal failure patients, ISAO $5: 54-58,1981$.

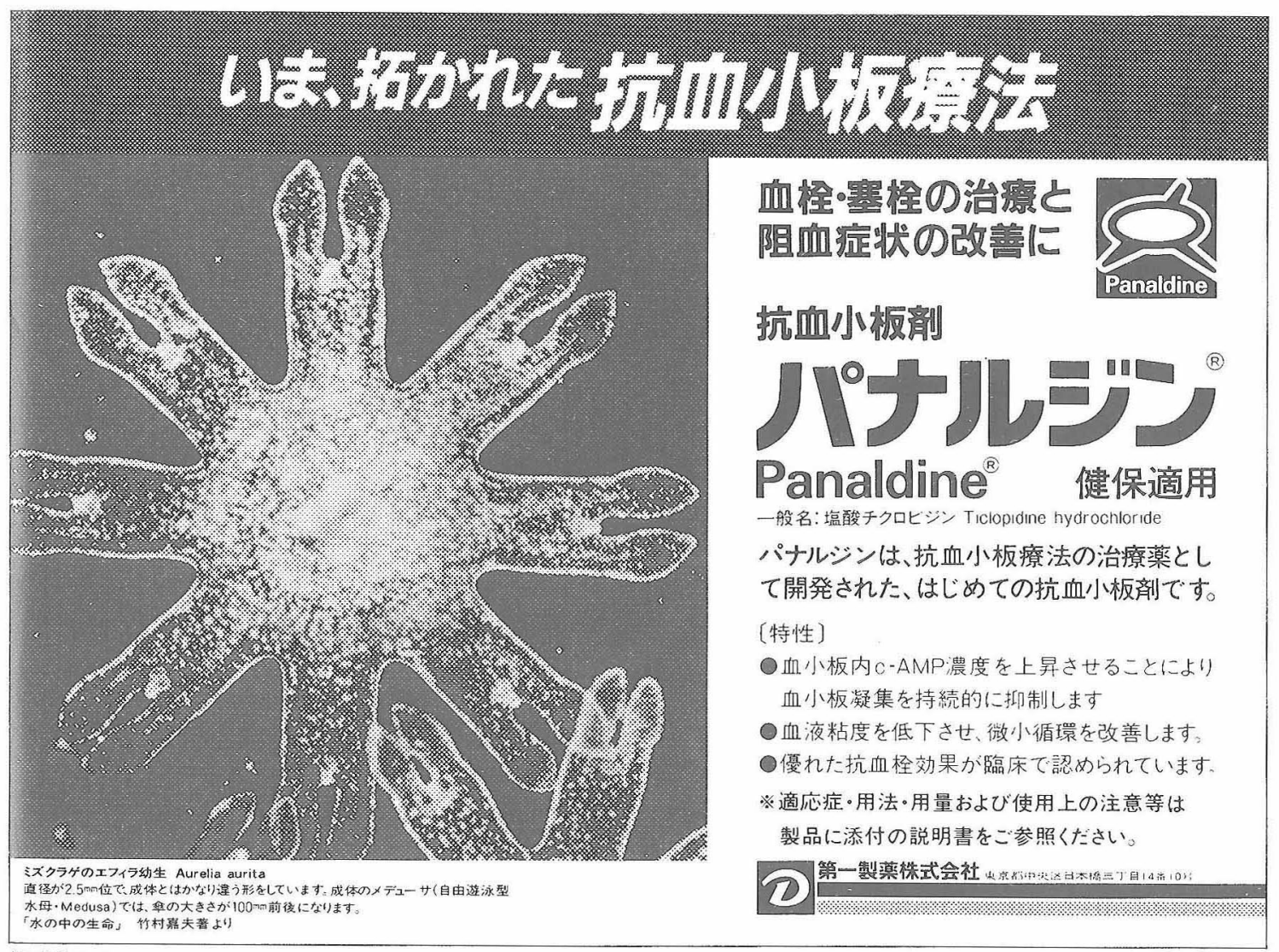

$\left(\mathrm{B} 5 \frac{1}{2}\right) 57.2$ 